\title{
Abnormal Copper Metabolism and Deficient Lysyl Oxidase Activity in a Heritable Connective Tissue Disorder
}

\author{
Helena Kuivaniemi, Leena Peltonen, Aarno Palotie, Ilkka Kaitila, and \\ KARI I. KIVIRIKKO, Departments of Medical Biochemistry and Anatomy, \\ University of Oulu, SF-90220 Oulu 22, Department of Medical Genetics and \\ Children's Hospital, University of Helsinki, SF-00290 \\ Helsinki 29, Finland
}

A B S T R A C T Biochemical abnormalities were studied in two brothers with bladder divericulas, inguinal hernias, slight skin laxity, and hyperelasticity and skeletal abnormalities including occipital exostoses. Lysyl oxidase activity was low in the medium of cultured skin fibroblasts, this abnormality being accompanied by reduced conversion of the newly synthesized collagen into the insoluble form. Copper concentrations were markedly elevated in the cultured skin fibroblasts, but decreased in the serum and hair. Serum ceruloplasmin levels were also low. The reduced lysyl oxidase activity is suggested to be responsible for the clinical manifestations, but the deficiency in this copper-dependent enzyme may be secondary to the abnormalities in the metabolism of the cation. Nevertheless, a mutation directly affecting both lysyl oxidase and an intracellular copper transport protein cannot be excluded. The disease is tentatively classified as one subtype of the Ehlers-Danlos syndrome.

\section{INTRODUCTION}

There are two practically identical X-linked recessively inherited disorders in which copper metabolism is grossly disturbed: the Menkes' kinky hair syndrome in man and mottled mutants in mice (1). The human disease is characterized by abnormalities of the hair, bones, and arteries, and by progressive cerebral degeneration with death usually by $3 \mathrm{yr}$ of age. In both diseases intestinal copper absorption is deficient, serum copper and ceruloplasmin concentrations are low, and cultured fibroblasts have markedly elevated amounts of this cation (1-3). The connective tissue abnormal-

Received for publication 6 November 1981. ities are probably due to a reduction in the activity of lysyl oxidase, a copper-dependent enzyme that initiates the cross-linking of collagen and elastin by catalyzing oxidative deamination of the $\epsilon$-amino groups in certain lysine and hydroxylysine residues (4). Lysyl oxidase activity is low in dietary copper deficiency (4) and in the mottled mouse mutants, whether assayed in tissue extracts (5) or in the medium of cultured fibroblasts (3). Assays in the medium of cultured Menkes' fibroblasts have provided conflicting data, however, as the values have been unaltered (4), slightly low (3), or markedly decreased (6).

We report here biochemical studies on two brothers who show distinct abnormalities in copper metabolism and low lysyl oxidase activity. The patients have several connective tissue abnormalities, but the clinical manifestations are distinctly different from those in the Menkes' syndrome.

\section{METHODS}

Patients. Two brothers, aged 22 yr (patient 1) and 9 yr (patient 2), of healthy parents have been followed from birth for identical clinical manifestations. The main problems have been bladder diverticulas from early childhood with ruptures from $13 \mathrm{yr}$ of age in patient 1 , inguinal hernias, and flat feet. The patients are of normal height and weight, their hand joints are hyperextensible, their skin is slightly lax and hyperelastic but not buisable, and their hair is coarse but not kinky. They also have skeletal abnormalities, a peculiar feature being occipital hornlike exostoses. Syncopic episodes have been present since infancy, but there are no distinct neurological abnormalities, and their EEG and the intellectual abilities are within normal limits. A detailed description of the clinical and radiographic findings and genetic data will be reported elsewhere. ${ }^{1}$

\footnotetext{
${ }^{1}$ Kaitila, I., L. Peltonen, and P. Lehtonen. Submitted for publication.
} 
TABLE I

Lysyl Oxidase Activity in the Medium of Cultured Fibroblasts

\begin{tabular}{lcc}
\hline & \multicolumn{2}{c}{ Lysyl oxidase activity } \\
\cline { 2 - 3 } Cell donor & Collagen substrate & Elastin substrate \\
\hline & $d p m / 10^{\circ}$ cells & $d p m / 10^{\circ}$ cells \\
Patient 1 & $180 \pm 60$ & $40 \pm 20$ \\
Patient 2 & $580 \pm 90$ & $250 \pm 60$ \\
Mother & $1,820 \pm 180$ & 690 \\
Father & $1,350 \pm 80$ & $590 \pm 110$ \\
Controls $(n=5)$ & & 890 \\
mean & 2,270 & $560-1,360$ \\
range & $1,260-3,330$ &
\end{tabular}

- Mean \pm SD of assays on three to four separate medium samples.

Fibroblast cultures. These were made from skin biopsies from the patients, their parents, and five apparently healthy controls of ages $1,11,11,38$, and $46 \mathrm{yr}$. The cells were grown in $65-\mathrm{cm}^{2}$ plastic tissue culture dishes in $10 \mathrm{ml}$ of Dulbecco's modification of Eagle's medium supplemented as described elsewhere (7). For the measurement of intracellular copper content or lysyl oxidase activity, fibroblasts that had just reached confluent density were incubated for $24 \mathrm{~h}$ in the above medium without serum. For the measurement of collagen extractability, the cells were labeled with $\left[{ }^{14} \mathrm{C}\right]$ proline as described in the legend to Table II and elsewhere (8).

Assays. $6-\left[{ }^{3} \mathrm{H}\right]$ lysine-labeled purified collagen $(8)$ and crude elastin (6) substrates were prepared as described elsewhere, except that $500 \mu \mathrm{Ci}$ of the isotope per 200 16-d chickembryo calvaria or $200 \mu \mathrm{Ci}$ per 30 aortae were used. Lysyl oxidase activity was assayed (8) with $0.8 \times 10^{6} \mathrm{dpm}$ of the collagen substrate or $1.8 \times 10^{6} \mathrm{dpm}$ of the elastin substrate, the incubation time with the enzyme being $10 \mathrm{~h}$. Four intracellular enzyme activities of collagen synthesis were measured as described elsewhere (7). All enzyme assays were carried out under conditions in which the relationship between the amount of enzyme added and the product formed was linear. The copper content of the fibroblasts (6) and the serum and hair (9) copper were measured by atomic absorption spectrophotometry, and serum ceruloplasmin was determined by using $p$-phenylenediamine as the substrate (10).

\section{RESULTS}

The clinical manifestations suggested a possible lysyl oxidase deficiency, as this enzyme plays a critical role in the mechanical strength of connective tissues. Because crude tissue extracts contain inhibitors of lysyl oxidase activity $(4,5)$ and because it is not possible to purify the enzyme from small tissue specimens, the assays were carried out with cultured skin fibroblasts. The media of the cells from the two patients had low lysyl oxidase activities against both collagen and elastin substrates, whereas no significant abnormality was found in the cell media of the parents (Table I). There was no significant difference in the degree of reduction in the enzyme activity from the 4-14th cell passage, and the cell media of patient 1 consistently had an even lower activity than those of patient 2 , the values being $5-10$ and $20-30 \%$ of the control mean, respectively. There was no abnormality in any of the four intracellular enzyme activities of collagen synthesis studied, i.e., prolyl 4-hydroxylase, lysyl hydroxylase, hydroxylysyl galactosyltransferase, or galactosylhydroxylysyl glucosyltransferase (data not shown).

The low lysyl oxidase activity was accompanied by a decrease in the percentage of the newly synthesized collagen that became insoluble during incubation of the cultured fibroblasts for $24 \mathrm{~h}$ (Table II).

Because lysyl oxidase deficiency has been associated with abnormalities of copper metabolism in the Menkes' syndrome $(3,6)$, the mottled mouse mutants $(3,5)$ and

TABLE II

Extractability of Newly Synthesized Collagen from Cell Layers of Cultured Fibroblasts

\begin{tabular}{lccc}
\hline & \multicolumn{3}{c}{${\text { Hydroxy[ }{ }^{[4} \text { Clproline }}^{*}$} \\
\cline { 2 - 4 } Cell donor & Extractable & Residue & Total \\
\hline & & $d p m / 10^{\circ}$ cells $(\%)$ & \\
Patient 1 & $12,850(91.6)$ & $1,180(8.4)$ & $14,030(100)$ \\
Patient 2 & $13,200(93.1)$ & $980(6.9)$ & $14,180(100)$ \\
Control 1 & $14,030(75.1)$ & $4,660(24.9)$ & $18,690(100)$ \\
Control 2 & $12,550(79.9)$ & $3,160(20.1)$ & $15,710(100)$ \\
\hline
\end{tabular}

- Confluent cultures were labeled with $8 \mu \mathrm{Ci}$ of $\left[{ }^{14} \mathrm{C}\right]$ proline for $24 \mathrm{~h}$. The cell layers were washed twice with phosphate-buffered saline, homogenized in $1 \mathrm{M} \mathrm{NaCl}$ and 50 $\mathrm{mM}$ Tris- $\mathrm{HCl}, \mathrm{pH} \mathrm{7.4}$, and extracted for $24 \mathrm{~h}$. The pellet remaining after centrifugation at $15,000 \mathrm{~g}$ for $30 \mathrm{~min}$ was extracted sequentially with $0.5 \mathrm{M}$ acetic acid and $8 \mathrm{M}$ urea, and the extracts and final residue were hydrolyzed in $6 \mathrm{M} \mathrm{HCl}$ at $120^{\circ} \mathrm{C}$ for $24 \mathrm{~h}$. Hydroxy $\left[{ }^{14} \mathrm{C}\right]$ proline was then assayed in each fraction (11). The values for extractable hydroxy $\left[{ }^{14} \mathrm{C}\right]$ proline represent the sum of those in the three extracts. 
TABLE III

Copper Concentrations in Serum, Hair, and Cultured Fibroblasts and Ceruloplasmin Concentration in the Serum

\begin{tabular}{lcccc}
\hline & \multicolumn{4}{c}{ Copper } \\
\cline { 2 - 4 } Subject & Serum & Hair & Fibroblasts & $\begin{array}{c}\text { Ceruloplasmin } \\
\text { serum }\end{array}$ \\
\hline & $\mu m o l / l i t e r$ & $n m o l / g d r y$ wt & $n m o l / 10^{\circ}$ cells & U/liter \\
Patient 1 & 6.6 & 80 & 6.2 & 15 \\
Patient 2 & 11.4 & 80 & 7.0 & 28 \\
Mother & 17.5 & 210 & 1.0 & 49 \\
Father & 19.5 & 250 & 0.9 & 32 \\
Normal & $12-22$ & $150-3801$ & $0.5-1.0$ & $36-65$ \\
\hline
\end{tabular}

- The normal values given for serum copper are the means of the upper and lower limits of those reported by six clinical laboratories for healthy adults, there being only minor differences between these. The normal values for serum ceruloplasmin are those given by the clinical laboratory in question. The limits for fibroblast copper were obtained from five cell lines assayed together with the cells from the patients and their parents.

$\downarrow$ Range of values reported with a very similar assay procedure by Harrison et al. (12).

an X-linked form of cutis laxa (8) assays were carried out to detect any abnormality in the concentration of this cation. The copper concentration was markedly high in the cultured skin fibroblasts from both patients, but low in the serum and hair (Table III). Serum ceruloplasmin concentration was also low, especially in patient 1 (Table III).

\section{DISCUSSION}

Most or all of the clinical manifestations, in the two patients are probably due to deficient lysyl oxidase activity. This activity was low in the medium of the cultured skin fibroblasts, and the abnormality was accompanied by reduced conversion of the newly synthesized collagen into the insoluble form. The defects demonstrated here in cultured cells are very likely to exist in vivo because studies on a number of heritable connective tissue disorders have indicated that a deficiency in lysyl oxidase $(3,5)$ or some other enzyme of collagen biosynthesis (13) found in cultured cells is also present in tissue extracts.

The abnormalities in copper metabolism resemble those found in the Menkes' syndrome and the mottled mouse mutants (1-3), although serum copper and ceruloplasmin concentrations are usually lower in the Menkes' syndrome. Some of the mouse mutants do not have reduced serum copper or ceruloplasmin in spite of the elevated copper concentrations in the cultured fibroblasts (3). The deficient lysyl oxidase activity may be secondary to a deficiency in functional intracellular copper (6), although the cellular concentrations of this cation are high. The possibility cannot be excluded, however, that the genes coding for lysyl oxidase and an intracellular copper transport protein may be closely located on the X-chromosome $(3,5)$ so that a single mutation will affect both these genes.

The clinical findings are distinctly different from those in the Menkes' syndrome. In particular, there is no evidence for arterial or neurological changes, and the disease is not lethal in childhood. The mottled mouse mutants, however, show a variety of clinical manifestations, some strains having mainly neurological and some vascular abnormalities $(1,5)$. The clinical findings are similar to those observed in some forms of the Ehlers-Danlos syndrome $(13,14)$, in particular a new X-linked subtype (15). After completion of the present study, we learned that patients with this subtype have reduced levels of desmosine cross-links of elastin and lysyl oxidase activity in the skin, and decreased serum copper and ceruloplasmin concentrations. ${ }^{2}$ Patients having an X-linked form of cutis laxa with low lysyl oxidase activity and serum copper and ceruloplasmin concentrations also have similar clinical manifestations (8), but our patients lack the marked skin laxity. No studies on fibroblast copper concentrations are currently available for the new Xlinked subtype of the Ehlers-Danlos syndrome or Xlinked cutis laxa, and thus it is not known whether these diseases have identical biochemical abnormalities. We tentatively suggest that our patients may be classified as one subtype of the Ehlers-Danlos syndrome with abnormal copper metabolism.

All the diseases discussed above have X-linked inheritance. A similar inheritance is possible in our pa-

\footnotetext{
${ }^{2}$ D. W. Hollister, R. C. Siegel, and J. Clark. Personal communication.
} 
tients. The female heterozygotes in the Menkes' syndrome do not usually have distinct abnormalities in their serum and fibroblast copper concentrations ( 1 , 2). Therefore the normal values found in the mother are not in disagreement with $\mathrm{X}$-linked inheritance.

\section{ACKNOWLEDGMENT}

This work was supported in part by grants from the Medical Research Council of the Academy of Finland.

\section{REFERENCES}

1. Danks, D. M. 1980. Copper deficiency in humans. In Biological Roles of Copper. Ciba Found, Symp. 79. Excerpta Med. Amsterdam. 209-225.

2. Goka, T. J., R. E. Stevenson, P. M. Hefferan, and R. R. Howell. Menkes disease: a biochemical abnormality in cultured human fibroblasts. Proc. Natl. Acad. Sci. U. S. A. 73: 604-606.

3. Starcher, B., J. A. Madaras, D. Fisk, E. F. Perry, and C. H. Hill. 1978. Abnormal cellular copper metabolism in the blotchy mouse. J. Nutr. 108: 1229-1233.

4. Siegel, R. C. 1979. Lysyl oxidase. Int. Rev. Connect. Tissue Res. 8: 73-118.

5. Rowe, D. W., E. B. McGoodwin, G. R. Martin, and D. Grahn. 1977. Decreased lysyl oxidase activity in the aneurysm-prone mottled mouse. J. Biol. Chem. 252: 939-942.

6. Royce, P. M., J. Camakaris, and D. M. Danks. 1980. Reduced lysyl oxidase activity in skin fibroblasts from patients with Menkes' syndrome. Biochem. J. 192: 579586.

7. Myllylä, R., K. Alitalo, A. Vaheri, and K. I. Kivirikko. 1981. Regulation of collagen post-translational modification in transformed human and chick-embryo cells. Biochem. J. 196: 683-692.

8. Byers, P. H., R. C. Siegel, K. A. Holbrook, A. S. Narayanan, P. Bornstein, and J. G. Hall. 1980. X-linked cutis laxa. Defective cross-link formation in collagen due to decreased lysyl oxidase activity. $N$. Engl. J. Med. 303: 61-65.

9. Salmela, S., E. Vuori, and J. O. Kilpiö. 1981. The effect of washing procedures on trace element content of human hair. Anal. Chim. Acta. 125: 131-137.

10. Rice, E. W. 1962. Standardization of ceruloplasmin activity in terms of international enzyme units. Anal. Biochem. 3: 452-456.

11. Juva, K., and D. J. Prockop. 1966. Modified procedure for the assay of $\mathrm{H}_{3}$ - or $\mathrm{C}^{14}$-labeled hydroxyproline. Anal. Biochem. 15: 77-83.

12. Harrison, W. W., J. P. Yurachek, and C. A. Benson. 1969. The determination of trace elements in human hair by atomic absorption spectroscopy. Clin. Chim. Acta. 23: 83-91.

13. Kivirikko, K. I., and E. R. Savolainen. 1981. Genetic disorders of collagen. Med. Biol. (Helsinki). 59: 1-6.

14. Hollister, D. W. 1978. Heritable disorders of connective tissue: Ehlers-Danlos syndrome. Pediatr. Clin. N. Am. 25: 575-591.

15. MacFarlane, J. D., D. W. Hollister, D. D. Weaver, K. D. Brand, L. Luzzatti, and A. A. Biegel. 1980. A new Ehlers-Danlos syndrome with skeletal dysplasia. Am. J. Hum. Genet. 32: 118A. 